\title{
About Drugs, Tickle and Laughter
}

\author{
Edson Olivari de Castro \\ UNESP, Bauru, Brazil
}

\begin{abstract}
This work aims, with some daily and clinical situations, a reflection on laughter mainstreamed by certain Freudian references, especially those on the joke and humor, pointing the furtive presence of death drive even when it seems at stake is the joy, the relief, consolation.

Keywords: psychoanalysis, death drive, drugs, laughing, tickling
\end{abstract}

To introduce the theme indicated initially I want to present two situations. The first is a banal scene: I was telling a friend some misfortune that happened to me recently to which he replied roaring with laughter. In fact the events bordered the disaster, then I wondered, where has he found reasons to laugh? The second is a clinical situation: an alcohol abuser patient invited to reflect on his insistence on the pursuit of the ultimate dose (The final one! Now the last drink! One more to finish the night) at the time he became aware that he has been guided by a desire for death, he laughed like a lost.

Let's highlight from these scenes this aspect: the discovery of a death wish, as well as the encounter with the tragic dimension can make someone laugh!

This banality, that is laughter, cannot be sufficiently understood by most of us, although it is a common presence in our daily lives and psychoanalysis has something to say about the phenomenon. Then I will dedicate myself to discuss some of that.

Freud did not carry out this work-although his interest in the joke-because he was satisfied with the theory of a neurologist of his time, named Spencer. This theory-initially adopted by the founder of psychoanalysis without much criticism - says that laughter is the release of a certain amount of energy whose accumulation proved to be useless.

Maybe Freud has accepted this explanation because it was a biological metaphor and an approximate causal hypothesis of a psychic phenomenon. But this way, we'd laugh because we've made provisions of "psychic energy" which proved to be useless and that is released into laughter. We would run more or less like a pressure cooker and its safety valve. Everything would be fine because with this explanation we would have the cause of laughter. But we lose its meaning, that by which psychoanalysis is more radically interested.

Interestingly, however, it is that the note 3 in Chapter VI of Wit and its Relation to the Unconscious (1905), we can read:

Many of my patients while under psychoanalytic treatment are wont to prove regularly by their laughter that I have succeeded in demonstrating faithfully to their conscious perception the veiled unconscious; they laugh also when the content of what is disclosed does not at all justify this laughter. To be sure, it is conditional that they have approached this unconscious closely enough to grasp it when the physician has conjectured it and presented it to them.

Edson Olivari de Castro, Ph.D., professor, supervisor, Psychology Department, Faculty of Sciences, UNESP. 
But having "approached this unconscious closely enough to grasp it" will be enough to laugh? And what to think about the fact that "they laugh also when the content of what is disclosed does not at all justify this laughter”?

Freud indices hardly give us references to the word laughter. If I'm not mistaken, almost all of them refer to the text of the Wit.

We know that a lapse produces a kind of restlessness when we do not disclose its meaning and that if we guess its meaning, it can make us laugh. Hence we can think of a relief, a tension that stops and makes from laughter the safety valve.

However, some other authors think that this can be explained even better for an annulment: evidenced specifically in compulsive acts and obsessive ceremonials of the Notes upon a Case of Obsessional Neurosis (1909), the retroactive annulment mechanism was explained by Freud in Inhibitions, Symptoms and Anxiety (1926 [1925]). He has two times, and the second is the deletion of the first, tending to transform an event as if it had not happened. Also involved in the repetition compulsion, which is made an effort to undo the traumatic experience, the purpose of cancellation refers therefore to the drives of destruction, or the death drive, to the extent that it would seek the annulment of tensions .

Thus, the attempt to eliminate the traces of a history or to erase a conflict may become a cancellation threat of the subject—via the signifier deletion that inscribed him. But when the desire comes into play through the transformation of passive into active (underlined by Freud on Female Sexuality (1931), as the children's game in which the subject actively repeat the experiences suffered passively), another route may open to the conflict instead of canceling it, it'll be able to present itself in a new way (Kaufmann, 1996, p. 44).

So we can think that anxiety and restlessness and anger when they are without justification, they metabolize into laughter. Here we have now an advantage over the safety valve approach because we enter into the problem of meaning, of the signified. ${ }^{1}$

Let us take a simple game pointed out by Freud - an opportunity for him to prove the existence of infantile sexuality - that is the laughter of tickling. If we do not doubt of infantile sexuality, we may doubt that tickles are a good example of its existence-after all, if it's all about sex, sex does not explain anything!

Of course there is a relationship between laughter and sex: the literature does not cease to produce examples, however, it is something very different: It is the ridiculous! Imagine the scene: a beautiful, manly guy comes into a nightclub with his girlfriend pulled by hand... gives an overall look, goes to a table and already calls on and starts struggling if she looks around, because he has already located, according to its own criteria of taste, the rival she will certainly flirt with and he will have to overcome strutting! If we laugh at that scene is more because of a sort of defense against megalomaniacal overvaluation of the phallus... comic by itself!

But maybe we can take the laughter of tickling as the first model of laughter, or as pointed out by Mannoni (1992, p. 68), all the causes that provoke it would foreshadow all other vicissitudes of laughter. Because there are also aggressive and defensive drives in tickles! They generate an ambiguous pleasure, mixed with a kind of anxiety-the child asks to stop before she has a painful convulsive reaction! But then the tickle resembles precisely the aggression... to laugh. And the child understands it so, that's why she laughs and defends herself at the same time.

\footnotetext{
${ }^{1}$ We are using the words "signifier" (signifiant), and “signified” (signifié), according to Saussure’s theory of the sign (1857-1913), reviewed by J. Lacan.
} 
Let's take a simple example: If we put a pet on your lap and do tickled, it reacts like this: he grasps, without biting the hand that caresses, shows the claws if it is a cat! It's its way of saying "Enough! Stop!”, a form of threat that opposes the threat... both to laugh about! It is not deceived that it is an aggression to laugh, and responds by inhibiting its aggression without, however, failing to express it! It is a beginning of communication, since it presupposes a further retention of a discharge excitation.

The important thing is that it can make us dismiss the idea that laughter was a reflex action. Note that a threat to tickle a child is enough to make her start laughing. And you cannot tickle yourself: this must be an interpersonal situation. The same does not occur, for example, with the knee-jerk reflex: the mere threat does not causes it and I cannot produce it in myself.

I mean, then, that the possibility that someone might respond with a defense of laughter (without mockery, although this is not very different) is something that, in a way, resembles the laughter of tickling: you cannot ward off feeling of danger, while knowing that the danger does not exist. Thus, the unrestrained laughter of the patient, to which I referred earlier, reveals that the unconscious death wishes never hurts anyone (except those who gives them shelter) and laughter at that revelation must have a meaning.

If the "rat man" (1909) had no desire to laugh when Freud addressed this issue, it is because he was too terrified at the unknown that Freud showed him and because the insistence of Freud at this point made the issue too serious!

We know there are laughs that are paradoxical, compulsive and frantic, embarrassing for those who are victims of them, scandalous for those who witness them, though often contagious: everyone must have heard Hebe Camargo telling how she, Lolita Rodrigues and Nair Bello, always find a silly thing in a funeral that makes them laugh compulsively, in a way that the three of them end up having to withdraw the exequies. ${ }^{2}$

What Mannoni (1992, p. 72) considers in the quoted text is that the desire for death becomes innocent when it becomes conscious. Even unconscious it was harmless, but it changes its nature, or place, when aware of it, to the point of making people laugh. It can be said that becoming aware of it, it becomes imaginary, it reveals its unreality.

But we have to understand well: the sense of the word "imaginary" is not the same when I identify myself with someone and feel embarrassed and when I imagine a friend coming for a visit long promised! The first "imaginary" refers to the order of speculation, it is unconscious and tends to the regulation of narcissistic fluctuations. The second depends on the fantasy, conscious fantasy and relates to the common situation of formulating ideas about the possibilities of the future.

Thus, when we say that the desire for death, when it becomes aware it becomes imaginary, it means that it is driven to that kind of existence that is the conscious fantasy, namely that reveals its unreality.

We know that Freud, in a letter to Fliess dated on September 21, 1897, writes that "there is no indication of reality in the unconscious". But this means that, for us, the death wish in the patient's unconscious is considered imaginary because it is not our unconscious, but his. The simple fact that the unconscious is unable to distinguish between the real and the imaginary, so that this distinction appears only at the expense of an awareness, which resembles the unconscious to a not criticized reality. Thus, an unconscious death wish is very different from a conscious desire of death, because for the last one, it is possible the management.

\footnotetext{
${ }^{2}$ The author refers to three starlets from Brazilian television that always made reference to the situation in interviews about their friendship.
} 
Let's take a look at another situation: a playful uncle covers himself with a sheet to scare his nephews. The children are frightened indeed. But the boldest pulls the sheet out and the uncle appears, so they burst out laughing. We could say that their fear was imaginary and that it was the discovery of the reality that freed them? But are there imaginary fears for those who feel fear? Or indeed, that's the opinion of one who is not afraid? If children were terrified is because the "ghost" was accepted as a not criticized reality... the fear was imaginary for the adults.

So, a death wish, as it is taken as unconscious can be considered a reality—and it becomes imaginary when we get aware of it. This is why the patient, quoted at the beginning of this text, laughed: the analyst tickled on his death wish. As the puppy laughs, in its way, when it considers that the distress or fear we cause it is not to be taken seriously, and starts defending itself with tooth and nail without harming...

If we generalize this idea, we can find that the anguish, tears, fear, anger, seem to form a group with laughter. They become — by annulment—each other. Any situation that may provoke them may raise laughter if it is recognized as a different thing that we believed before! And we laugh at our tears, fear and anger, at our misfortune and at someone's else.

And we think that, even for wits analyzed by Freud: just admit that the lapse, the apparent error, the nonsense initially presented to a listener produce a primary defense, which is the will to be indignant or to correct, or even to get irritated and the laughter that will be replacing the negative reaction is like abandoning this defense, the pressure resolution —and that's not all, because it also involves going from the opposition to complicity: to laugh with others, as the little animal playing the game of reciprocal threats!

Perhaps if we passed in review all the opportunities we have to laugh, we would find that laughter is always a reaction to something negative, hostile, frightening or distressing, but in such a way that we can accept all this as a trifiling hoax!

There is always a way—even when things go wrong and nothing can be done—-to resort to laughter, and this desperate measure is called humor: that makes others laugh, but not the humorist, or rarely. ${ }^{3}$

And here we reach a last point I would like to highlight. If we understand the constitution of the psychic apparatus in Freud we might think that there is no more precise vector drive than the superego, because what speaks for this instance-living heir of parental instance - would be the voice, as alive as devitalized, of the drive. The superego, then, would not only be a severe master, but in itself, despite its austerity and its ferocity, an instinctual operator as it is with the power of the Id that it reinvests the utterances heard before. What can we say of humor, when it fills the self consolation function? In fact, who speaks by the humoristic utterance-“Look! Here's the world that seems so dangerous! It's nothing more than just a game for children, worthy only for making a joke" — but the superego, that we usually think that never derides, never mocks, it is never kidding?

With the humorous attitude, then, Freud writes, we refuse citizenship to pain without leaving the field of mental health. The humor is inserted, therefore, "in the great number of methods that the psychic life of man built in order to escape from the oppression of pain, series that opens with the neurosis and madness, and also covers drunkenness, closing in itself, ecstasy” (Humor, 1927).

Finally, I think, then, that we may understand that the laughter of a patient or of an analyst during a session

\footnotetext{
3 There are several studies on laughter related to humor: We can name a few as an example: Kupermann, D. (2003). Ousar rir: humor, criação e psicanálise. Rio de Janeiro: Civilização Brasileira e Kupermann, D. \& Slavutsky, A. (orgs.). (2005). Seria trágico... se não fosse cômico: humor e psicanálise. Rio de Janeiro: Civilização Brasileira.
} 
at the time that it reveals the meaning of a speech that releases something of the unconscious is a sign that an obstacle was removed.

And the very serious man, the one who goes down or puts the analyst in a position of control and the patient, it can be said, in a position of eager anticipation, does not have the same virtues—I think. Knowledge, in its relation to the unconscious, cannot have the same effect and would also not provide the same proofs-not to mention that often seems to me emotionally ineffective.

None of us ever had or will miss someone purporting to be a master of himself and of the situation... They can be found anywhere, in droves, daily... but if there is one thing that the psychoanalyst should avoid it is precisely being taken by a lord and master of this kind.

\section{References}

Freud, S. (2000). Cartas à Fliess (21 de setembro de 1897). Edição Eletrônica Brasileira das Obras Psicológicas Completas de Sigmund Freud, versão 2.0. Volume II. Rio de Janeiro: Imago.

Freud, S. (2000). Notas sobre um caso de neurose obsessiva (1909). Edição Eletrônica Brasileira das Obras Psicológicas Completas de Sigmund Freud, versão 2.0. Volume X. Rio de Janeiro: Imago.

Freud, S. (2000). Inibições sintoma e angústia (1926[1925]). Edição Eletrônica Brasileira das Obras Psicológicas Completas de Sigmund Freud, versão 2.0. Volume XX. Rio de Janeiro: Imago.

Freud, S. (2000). Sexualidade feminina (1931). Edição Eletrônica Brasileira das Obras Psicológicas Completas de Sigmund Freud, versão 2.0. Volume XXI. Rio de Janeiro: Imago.

Freud, S. (2000). O humor (1927). Edição Eletrônica Brasileira das Obras Psicológicas Completas de Sigmund Freud, versão 2.0. Volume XXI. Rio de Janeiro: Imago.

Freud, S. (2000). O chiste e sua relação com o inconsciente (1905). Edição Eletrônica Brasileira das Obras Psicológicas Completas de Sigmund Freud, versão 2.0. Volume VIII. Rio de Janeiro: Imago.

Kaufmann, P. (1996). Dicionário Enciclopédico de psicanálise: O legado de Freud e Lacan. Rio de Janeiro: Zahar Ed..

Mannoni, O. (1992). Um espanto tão intenso. Rio de Janeiro: Ed. Campus. 